\title{
Developing Training Evaluation Instrument for Teachers of Elementary School and Early Childhood Education in Pekanbaru, Riau
}

\author{
Iqbal Miftakhul Mujtahid, Universitas Terbuka, iqbal@ecampus.ut.ac.id, ORCID: 0000-000-9577-8736 \\ Mery Berlian, Universitas Terbuka, mery@ecampus.ut.ac.id, ORCID: 0000-0003-1736-2684 \\ *Rian Vebrianto, Universitas Islam Negeri Sultan Syarif Kasim Riau, rian.vebrianto@uin-suska.ac.id, \\ ORCID: 0000-0002-2958-6821 \\ Musa Thahir, Universitas Islam Negeri Sultan Syarif Kasim Riau, musa.thahir@uin-suska.ac.id, \\ ORCID: 0000-0001-8084-5908 \\ *Corresponding author
}

\begin{abstract}
As an attempt to achieve successful learning in classroom, teachers are required to always learn and increase their potential, especially in using teaching aids. However, lack of teaching aids facilities and lack of development of evaluation instrument become main issues faced by teachers. Thus, it is necessary to develop training evaluation instrument for teachers. This research utilized a theoretical development model in instrument standardization activities. There were 30 respondents collected through an online questionnaire which were then analyzed using SPSS version 23.00 for Windows. Results showed that: 1) results of validity and reliability test showed that validity of training evaluation instrument for teachers met valid criteria. Construct validity was tested through factor analysis including material content, material presentation, discussion/question and answer, and group work practices; and 2) reliability of training evaluation instrument for teachers prepared and developed in this research met quite high category as indicated by alpha reliability coefficient of 0.935 .
\end{abstract}

Keywords: Instrument Development, Training Evaluation, Elementary School and Early Childhood Education Teachers, Validity, Reliability

$\begin{array}{lll}\text { Received: 20.11.2020 } & \text { Accepted: 08.12.2020 } & \text { Published: 13.01.2021 }\end{array}$

\section{INTRODUCTION}

One of elaborations of government, community, and professional organization responsibilities is providing guidance and mentoring for teachers as an attempt to encourage them to carry out their duties and functions to maximum extent. One of main duties and functions of a teacher is to make learning tools/teaching aids (Sudarwanto \& Hadi, 2014); (Baharuddin, 2016). Teaching aids in learning process can increase interest, motivation, and make it easier for students to understand subject materials. It is in line with an opinion (Haryanto \& Wahyudi, 2017) which stated that learning media can attract students' attention so that they are more motivated in learning process that later their understanding and learning achievement can increase. It is very helpful to facilitate students in understanding a lesson. Furthermore, it is stated that use of teaching aids in learning process is expected to assist teachers in demonstrating a related natural science concept, so that it is easier for students to understand the concept (Saputri \& Dewi, 2014). It is supported by an opinion stating that teaching aids help teachers to convey concept of natural science to be more meaningful (Prasetyarini et al., 2013). Results of previous research also revealed that post-test results of students in class with teaching aids increase by 12.41 or $14.79 \%$ (Andriya et al., 2013). In addition, learning by using teaching aids is a series of activities to deliver subject materials that aims to give students opportunities to actively learn so as to enable them to gain knowledge and develop psychomotor skills and foster their creativity to solve problems faced (Putranti, 2013).

Learning Natural Science is expected to be a tool for students to learn themselves, natural surroundings, and prospects for further development in applying them in everyday life. To develop competencies so as to explore and understand natural environment scientifically, the learning process emphasizes providing direct experience. Natural Science Education is directed to inquiry and as an effort to help students gain a deeper understanding of natural surroundings (Yuliyanti, 2016). In this case, practicing in learning activities is a 'spirit' of Natural Science. An important point is that practical activities are inseparable from teaching aids and materials. This is because Educational Teaching Aids (Alat Peraga Edukatif/APE) have a very important role in learning, such as training children's 
concentration; teaching faster and effectively; overcoming issues in terms of limited time, place and language; arousing human emotions; increasing students' understanding and memory; and increasing freshness in teaching (Hijriati, 2017). It is supported by an idea that says that APE has several functions in learning, including: 1) supporting the effective and pleasant implementation of children's learning; 2) as a medium that can stimulate a child's activity to learn something without realizing it and is designed multipurpose; and 3) optimizing children's development (Astini et al., 2017). Thus, use of teaching aids related to problems in daily life is an integral part of the whole learning process. It implies that APE of Natural Science in learning is one of components that is integrated with other components in order to create expected learning situation (Rosita \& Eko, 2014). Accordingly, APE of Natural Science is an absolutely necessary component.

Based on the aforementioned explanation, it is clear that a teacher must have an ability and skills to create a simple APE of Natural Science to increase achievement of learning goals in school as required in curriculum. However, that not all schools/madrasas have teaching aids or laboratories is an issue in implementation of APE. This is frequentky used as an excuse by teachers that practicum in learning Natural Science cannot be conducted due to absence of supporting teaching aids and laboratories. It is in line with results of previous research that shows that: 1) teacher chooses to use lecture method to deliver learning material because supporting aids are not yet available (Saputri \& Dewi, 2014); 2) problems of using teaching aids is often ignored for various reasons (Murdiyanto \& Mahatma, 2014); and 3) Ichthyology practicum learning is based on subject of scientific disciplines, theunavailability of teaching aids that support assistant/person in charge of particular course (Budiyanto, 2015).

Besides improving learning process implemented, improving quality of learning can be done through improvements to assessment used to measure learning outcomes. Improvements in assessment aspect can be done by providing guidance and training in conducting assessment (Kartowagiran et al., 2016). An assessment used to obtain, synthesize and interpret information obtained from students with the aim of drawing decisions about students in classroom is known as classroom assessment. Classroom assessment used to assess student performance during learning is known as assessment for learning (Yazd, 2009). In learning process, assessment for learning integrates with learning implementation plan that is prepared or used by teacher. One of forms of assessment for learning is performance assessment. Performance assessment is used to assess ability of students to translate their understanding into real work, so that it basically can show true abilities of students. To be feasible to use, instruments used in assessment have two requirements, namely valid and reliable (Samsul \& Mutmainnah, 2018); (Scholtes et al., 2010); (Sitzia, 1999). Based on these reasons, training on evaluation instrument for teachers who have been developed previously must meet both of these requirements. Consequently, it is necessary to conduct validity and reliability test on assessment instruments for training evaluation performance.

Based on the importance of using teaching aids, an appropriate assessment instrument is needed in order to evaluate and provide improvements and training to increase the use of teaching aids. Therefore, this study aimed to develop and validate training evaluation instrument for teachers to find out effectiveness of assistance in development of teaching aids.

\section{METHODS}

This research utilized a development model in instrument standardization activities. The method of development in research uses a theoretical model that is a model that illustrates the framework of thinking based on relevant theories and is supported by empirical data (Silalahi, 2017). The following are steps of research carried out: 1) conducting theoretical studies to formulate aspects or indicators of assisting development of teaching aids, 2) arranging instrument lines, 3) arranging instrument items, 4) conducting expert judgment, 5) conducting try-out, 6) conducting analyzes, 7) revision, and 8) formulating final instrument of research results (Susiatin, 2019); (K. Hayati \& Listyani, 2010). This research was conducted at SDIT Al-Ikhwan Pekanbaru in odd semester of 2020/2021 academic year. For the purpose of testing instrument, population were all participants of assistance activities for development of teaching aids as many as 30 people. Since population was less than 100 people, sample used was all participants (Alwi, 2012); (Hendri, 2015). Operational variable in this research was training evaluation. Furthermore, specification of contents of training evaluation instrument was done by first describing concepts of training evaluation into a construct that revealed evaluation of teacher training. Each construct had different statement items. In accordance with characteristics of type of response, format of measuring instrument used is Likert scale, in which each statement had 5 items of alternative answers, including Strongly Agree (SA) with a score of 5, Agree (A) with a score of 4, Neutral (N) with a score of 3, Disagree (D) with a score of 2, and Strongly Disagree (SD) with a score of 1. 
To produce a quality instrument and can measure what should be measured, the level of validity and reliability of the questionnaire instrument with a scale of 5 (Li, 2013) was assessed. Data obtained from distribution of training evaluation questionnaire instrument at SDIT Al-Ikhwan Pekanbaru was subsequently processed using Statistical Package for Social Sciences (SPSS) (Rizta \& Antari, 2018); (Kusumah \& Perdana, 2018); (Bashooir \& Supahar, 2018) to determine quality of instrument developed. Researchers determined validity of this instrument by using item correlation value that was corrected by total score without item regarding following dimensions or constructs. Reliability Index was obtained by using Cronbach's Alpha. Based on analysis conducted, validity value by using correlation value of items that were corrected shall have a minimum value of 0.3 (Nunnally, 1978) and instrument reliability based on results of Cronbach's Alpha analysis needed to have value above 0.6 and below 1 (Joseph F. Hair et al., 2006). Therefore, this research could produce good quality instruments.

\section{RESULTS}

In this research, preparation and method of developing training evaluation instrument for teachers were carried out using a theoretical development model. The research began with a theoretical study to formulate a training evaluation construct for teachers. Based on a study of various theories about training evaluation, four training evaluation constructs for teachers were finally compiled: 1) material contents, 2) material presentation, 3) discussion/question and answer, and 4) group work practices. The following is guideline of training evaluation instrument for teachers.

Table 1. Guideline of Training Evaluation Instrument for Teachers

\begin{tabular}{|c|l|l|}
\hline No & \multicolumn{1}{|c|}{ Construct } & \multicolumn{1}{c|}{ Item Number } \\
\hline 1 & Material Contents & $1,2,3$, and 4 \\
\hline 2 & Material Presentation & 5,6, and 7 \\
\hline 3 & Discussion/Question and Answer & 8,9, and 10 \\
\hline 4 & Group Work Practices & $11,12,13,14$, and 15 \\
\hline
\end{tabular}

Table 1 shows that there are 15 statement items spread into four constructs. Researchers compiled statement using Likert scale after compiling instrument guideline in each construct After instrument was arranged, expert judgment was carried out by consulting to evaluation expert. Based on expert judgment, there were some improvements to some statements that were less precise with constructs. After revision was made, researchers conducted try-out on 30 SDIT Al Ikhwan teachers. Based on try-out data, the next step was conducting an analysis to find out validity and reliability of training evaluation instrument for teachers that had been prepared. One of most important stages of research is design of measurement instruments equipped with validity and reliability tests. Construct validity is a picture that shows how far measuring instrument shows results that are in accordance with theory (Ihsan, 2015). Emory mentioned several methods that can be used to measure construct validity: consideration of correlation between research data with existing measurement methods, convergent discriminant techniques, factor analysis, and multi method analysis (Fahruna \& Fahmi, 2017). Minimum standard of validity used by researchers was based on a comparison between calculated individual coefficient value (r-count) and Pearson coefficient table value ( $r$-table). Question items on questionnaire are declared valid if value of $r$-count $>r$ table (Triana \& Oktavianto, 2013). Validity of this instrument utilized corrected item-total correlation value with total score without item regarding dimensions or constructs. Moreover, Nunnally (1978) pointed out that correlation between items with a score that exceeds 0.25 is considered a high value. In this research, researchers determined research instrument validity using item correlation values corrected by corrected item-total correlation in terms of dimensions or construction. Based on analysis conducted, results of instrument validity test from data are shown in Table 2 below.

Table 2. Instrument Validity Using Item Correlation Values and Corrected Item-Total Correlation for Each Construct

\begin{tabular}{|c|c|c|c|}
\hline Construct & Item & $\begin{array}{c}\text { Corrected Item-Total } \\
\text { Correlation }\end{array}$ & $\begin{array}{c}\text { Cronbach's Alpha if } \\
\text { Item Deleted }\end{array}$ \\
\hline Material Contents & 1 & .844 & .973 \\
\cline { 2 - 4 } & 2 & .858 & .973 \\
\cline { 2 - 4 } & 3 & .803 & .974 \\
\cline { 2 - 4 } & 4 & .882 & .972 \\
\hline Material Presentation & 5 & .874 & .973 \\
\hline
\end{tabular}




\begin{tabular}{|l|c|c|c|}
\hline \multicolumn{1}{|c|}{ Construct } & Item & $\begin{array}{c}\text { Corrected Item-Total } \\
\text { Correlation }\end{array}$ & $\begin{array}{c}\text { Cronbach's Alpha if } \\
\text { Item Deleted }\end{array}$ \\
\hline \multirow{4}{*}{$\begin{array}{l}\text { Discussion/Question } \\
\text { and Answer }\end{array}$} & 6 & .719 & .975 \\
\cline { 2 - 4 } & 7 & .866 & .973 \\
\cline { 2 - 4 } & 8 & .833 & .973 \\
\cline { 2 - 4 } & 10 & .807 & .974 \\
\hline Group Work Practices & 11 & .854 & .973 \\
\cline { 2 - 4 } & 12 & .806 & .974 \\
\cline { 2 - 4 } & 13 & .881 & .972 \\
\cline { 2 - 4 } & 14 & .820 & .973 \\
\cline { 2 - 4 } & 15 & .843 & .973 \\
\hline
\end{tabular}

Based on Table 2, value of r-table is 0.306 obtained from tables with degrees of freedom ( $\mathrm{df}$ ) of 28 of 15 questionnaires distributed as try-out. From overall calculation, all items were declared valid since value of r-count > r-table. Accordingly, all items of questions could be used to measure training evaluation for teachers.

In developing training evaluation instrument for teachers, each item was assessed for internal consistency. It was a measure of extent to which items on a scale measure similar construct as other items on the same scale. In this case, items that were not highly correlated with their respective scales were deleted and data were re-analyzed until all items with the lowest item scale correlation were removed and alpha coefficients were maximized. Table 3 illustrates reliability scale using Cronbach's alpha coefficient for a set of questionnaires based on training evaluation instrument for teachers.

Table 3. Cronbach's Alpha Reliability Index for Each Construct

\begin{tabular}{|l|c|}
\hline \multicolumn{1}{|c|}{ Construct $(\mathbf{N}=\mathbf{3 0})$} & Overall Cronbach's Alpha Value \\
\hline Material Contents & .929 \\
\hline Material Presentation & .935 \\
\hline Discussion/Question and Answer & .953 \\
\hline Group Work Practices & .923 \\
\hline
\end{tabular}

Cronbach's Alpha Reliability Index values for each construct in this research and overall alpha value obtained indicated for material contents, material presentation, discussion/question and answer, and group work practices respectively were $0.929 ; 0.935 ; 0.953$; and 0.923 . In this research, it was found that reliability value $(\alpha)$ was greater than 0.60 for each construct studied. This result supports an idea of Basuki and Haryanto. They strongly advocated that correlation numbers above 0.60 and less than 1 indicate that instrument has high correlation or reliable. On the other hand, correlation numbers below 0.50 indicate that instrument has a low correlation or is not reliable (Arifin, 2017; Hair et al. 2006). Thus, four results of reliability analysis above proved that all questionnaires used in this study had been declared reliable.

Results of this research indeed showed that training evaluation instrument for teachers which were declared valid and reliable still need to be reviewed in order to obtain standardized instruments. This is because try-out was only conducted once. It is better if it is done more than once so that better consistency can be achieved. In addition, formula used does not utilize new measurement theory that is item response theory so that error or estimation error is very likely to affect results obtained.

\section{DISCUSSION AND CONCLUSION}

After going through several stages of research, a final product was produced in the form of training evaluation instrument for teachers which already met good test criteria. Product contained 15 statement items which were packaged in a form of an online questionnaire using Google form. This research was strengthened by previous research which stated that assessment instruments developed had met valid criteria based on results of validity test analysis of practice assessment instrument (Azzahri et al., 2017). Furthermore, findings of research conducted by Inteni et al., stated that instrument developed was appropriate for use by both teachers and students because it met standards of validity, reliability, difficulty level of questions, and different power (Aji \& Winarno, 2016); (Adamsa \& Wieman, 2010). Moreover, cognitive learning achievement test instruments that had been developed met valid categories (Nurfillaili et al., 2016). Validity is defined as an ability of instrument to measure attributes of construct 
under study (DeVon et al., 2007). A valid instrument has high validity. Conversely, an instrument that is less valid means it has low validity (Efendi \& Widodo, 2019); (Wales et al., 2017). Results of validation of instrument in the form of a training evaluation instrument for teachers which are declared valid and appropriate to be used as a measurement tool for evaluating quality of training evaluation instruments.

Most importantly, results also showed that composite coefficient of reliability score achieved by training evaluation scale for teachers was included in high category (0.935). However, it should be noted that reliability coefficient of each construct is from 0.719 to 0.923 . Based on consensus that satisfactory reliability is achieved at a coefficient of 0.6 or more, this value indicates that reliability of each subscale in training evaluation scale for teachers used in this research is satisfactory (Khumaedi, 2012). Additionally, reliability measurement is very dependent on researchers in using criteria used (Khumaedi, 2012). It is supported by previous research which claims that instruments of Active, Creative, Effective and Fun learning (PAKEM) have validity and reliability values that suitable for use in measuring PAKEM strategy knowledge for teachers (S. Hayati \& Lailatussaadah, 2016). Results of instrument reliability were also in the form of training evaluation instrument for teachers which was declared reliable to be used as a measurement tool for evaluating quality of training evaluation instrument.

Based on analysis conducted, questionnaire developed based on training evaluation instrument for teachers has good construct validity and high reliability so that it can be used in research on development of teaching aids. Thus, research instrument that measures training evaluation for teachers that has been tested is declared worthy of use and trusted in research that measure training evaluation for teachers. It is in line with a research which believed that instruments that are valid and reliable can be used as measurement tools (Suratno, 2016). Moreover, use of evaluation instrument must meet valid criteria and be appropriate for use (Pinilih et al., 2013). Results of assessment using instrument made need to be able to comprehensively inform training evaluation for teachers while carrying out research activities. Training evaluation instrument for teachers can prevent speculative actions from teachers to conduct assessment, especially in determining final grade after conducting research on achievement of training evaluation.

Fundamentally, development of training evaluation instrument for teachers is a follow-up to an implementation of education standardization policies through issuance of Government Regulation No. 19/2005, Article 63-72 and Regulation of the Minister of National Education Number 20 of 2007 on Standards for Educational Assessment. It is stated that educational assessment at tertiary level is regulated by each tertiary institution in accordance with applicable laws and regulations (Astuti et al., 2015). Implementation of this policy requires each researcher to be able to produce a number of assessment instruments in accordance with established competency standards. Unfortunately, this instrument does not involve enough respondents from SDIT Al Ikhwan Pekanbaru teachers and may not necessarily be suitable for use as research instruments in other schools. Further research can be done to see validity and reliability of respondents in other schools and with a larger sample of respondents. Additionally, further research is conducted in order to make this research instrument better and level of validity and reliability is getting higher by which this instrument can be used as a more precise research tool to obtain research data.

Based on results of research and discussion, several conclusions can be drawn: 1) preparation and development of training evaluation instrument for teachers in this study are carried out using a theoretical development model with the following steps: a) carrying out theoretical studies to formulate aspects or indicators of assisting development of teaching aids, b) compiling instrument guideline, c) compiling instrument items, d) conducting expert judgment, e) conducting try-out, f) conducting analyzes, g) revision, and h) formulating final instrument of research results; and 2) results of validity and reliability tests show that validity of training evaluation instrument for teachers meets valid criteria. Importantly, construct validity is tested through factor analysis, including material contents, material presentation, discussion/question and answer, and group work practices; and 3) reliability of training evaluation instrument for teachers prepared and developed in this research has met quite high category as indicated by alpha reliability coefficient of 0.935 .

\section{REFERENCES}

Adamsa, W. K., \& Wieman, C. E. (2010). Development and validation of instruments to measure learning of expert-like thinking. International Journal of Science Education, 33(9), 1-24. https://doi.org/10.1080/09500693.2010.512369

Aji, B. S., \& Winarno, M. E. (2016). Pengembangan Instrumen Penilaian Pengetahuan Mata Pelajaran Pendidikan Jasmani Olahraga dan Kesehatan (PJOK) Kelas VIII Semester Gasal. Jurnal Pendidikan, 1(7), 1449-1463. 
Alwi, I. (2012). Kriteria Empirik Dalam Menentukan Ukuran Sampel Pada Pengujian Hipotesis Statistika dan Analisis Butir. Formatif: Jurnal Ilmiah Pendidikan MIPA, 2(2), 140-148. https://doi.org/http://dx.doi.org/10.30998/formatif.v2i2.95

Andriya, K., Abdurrahman, \& Yudiono, H. (2013). Peningkatan Pemahaman tentang Prinsip Kerja Differential dengan Menggunakan Media Peraga Differential Cutting. Automotive Science and Education Journal, 2(1), 1-4.

Arifin, Z. (2017). Kriteria Instrumen Dalam Suatu Penelitian. Jurnal Theorems (the Original Research of Mathematics), 2(1), 28-36.

Astini, B. N., Nurhasanah, Rachmayani, I., \& Suarta, I. N. (2017). Identifikasi Pemnafaatan Alat Permainan Edukatif (APE) Dalam Mengembangkan Motorik Halus Anak Usia Dini. Jurnal Pendidikan Anak, 6(1), 31-40. https://doi.org/10.1017/CB09781107415324.004

Astuti, W. P., Wibawanto, H., \& Khumaedi, M. (2015). Pengembangan Instrumen Penilaian Unjuk Kerja Praktik Perawatan Kulit Wajah Berbasis Kompetensi di Universitas Negeri Semarang. Journal of Educational Research and Evaluation, 4(2), 8-14.

Azzahri, C. K., Widjanarko, D., \& Sudana, I. M. (2017). Pengembangan Instrumen Penilaian Praktik Rias Pengantin Jogja Paes Ageng pada Mata Kuliah Rias Pengantin Jawa. Journal of Vocational and Career Education, 2(1), 22-27. https://doi.org/10.15294/jvce.v2i1.10928

Baharuddin. (2016). Penggunaan Alat Peraga Dengan Pembelajaran Langsung Dalam Meningkatkan Motivasi Mengajar Guru di SD Negeri 010 Pagaran Tapah Darussalam Kabupaten Rokan Hulu. Jurnal Primary, 5(3), 700-712. https://doi.org/10.33578/pjr.v2i6.6545

Bashooir, K., \& Supahar. (2018). Validitas dan Reliabilitas Instrumen Asesmen Kinerja Literasi Sains Pelajaran Fisika Berbasis STEM. Jurnal Penelitian Dan Evaluasi Pendidikan, 22(2), 168-181. https://doi.org/10.21831/pep.v22i2.20270

Budiyanto, A. (2015). Pengembangan Alat Peraga Sederhana Struktur dan Organ Dalam Ikan untuk Mempermudah Pembelajaran Pada Praktikum Ikhtiologi Perikanan. Jurnal Kelautan, 8(2), 83-88.

DeVon, H. A., Block, M. E., Moyle-Wright, P., Ernst, D. M., Hayden, S. J., Lazzara, D. J., Savoy, S. M., \& KostasPolston, E. (2007). A psychometric toolbox for testing validity and reliability. Journal of Nursing Scholarship, 39(2), 155-164. https://doi.org/10.1111/j.1547-5069.2007.00161.x

Efendi, Y., \& Widodo, A. (2019). Uji Validitas dan Reliabilitas Instrumen Tes Schooting Sepak Bola Pada Pemain Tim Persiwu FC Jatiyoso. Jurnal Kesehatan Olahraga, 7(2), 367-372.

Fahruna, Y., \& Fahmi, M. (2017). Validitas dan Reliabilitas Konstruk Pengukuran Perpustakaan Ideal Berbasis Pemakai dengan Pendekatan LIBQUAL. Jurnal Ekonomi Bisnis Dan Kewirausahaan, 6(2), 161. https://doi.org/10.26418/jebik.v6i2.22989

Haryanto, M. A. K., \& Wahyudi. (2017). Pengembangan Media Peraga untuk Pembelajaran Kompetensi Mengidentifikasi Final Drive Penggerak Roda Belakang. Jurnal Pendidikan Teknik Mesin, 17(1), 2531.

Hayati, K., \& Listyani, E. (2010). Pengembangan Instrumen Kemandirian Belajar Mahasiswa. In Jurnal Penelitian dan Evaluasi Pendidikan (Vol. 14, Issue 1, pp. 84-100). https://doi.org/10.21831/pep.v14i1.1977

Hayati, S., \& Lailatussaadah. (2016). Validitas dan Reliabilitas Instrumen Pengetahuan Pembelajaran Aktif, Kreatif, dan Menyenangkan (PAKEM) Menggunakan Model RASCH. Jurnal Ilmiah DIDAKTIKA, 16(2), 169-179.

Hendri, H. J. (2015). Survei Minat dan Motivasi Siswa Putri Terhadap Mata Pelajaran Penjasorkes di SMK se-Kota Salatiga Tahun 2013. Active - Journal of Physical Education, Sport, Health and Recreation, 4(4), 1729-1736. https://doi.org/10.15294/active.v4i4.4855

Hijriati. (2017). Peranan dan Manfaat APE untuk Mendukung Kreativitas Anak Usia Dini. Bunayya : Jurnal Pendidikan Anak, 3(2), 59-69. https://jurnal.ar-raniry.ac.id/index.php/bunayya/article/view/1699

Ihsan, H. (2015). Validitas Isi Alat Ukur Penelitian: Konsep dan Panduan Penilaiannya. PEDAGOGIA Jurnal Ilmu Pendidikan, 13(3), 173. https://doi.org/10.17509/pedagogia.v13i3.6004

Joseph F. Hair, J., Black, W. C., Babin, B. J., \& Anderson, R. E. (2006). Multivariate Data Analysis. Pearson Educational International.

Kartowagiran, Badrun, Jaedun, \& Amat. (2016). Model Asesmen Autentik untuk Menilai Hasil Belajar Siswa Sekolah Menengah Pertama (SMP): Implementasi Asesmen Autentik di SMP. Jurnal Penelitian Dan Evaluasi Pendidikan, 20(2), 131-141. https://doi.org/10.21831/pep.v20i2.10063

Khumaedi, M. (2012). Reliabilitas Instrumen Penelitian Pendidikan (The Reliability of Education Research Instruments). In Jurnal Pendidikan Teknik Mesin (Vol. 12, pp. 25-30).

Kusumah, \& Perdana, E. (2018). Technology Acceptance Model (TAM) of Statistical Package for the Social Sciences (SPSS) Applications. Integrated Journal of Business and Economics, 2(1), 1-11. https://doi.org/10.33019/ijbe.v2i1.47 
Li, Q. (2013). A Novel Likert Scale Based on Fuzzy Sets Theory. Expert Systems with Applications, 40(5), 1609-1618. https://doi.org/10.1016/j.eswa.2012.09.015

Murdiyanto, T., \& Mahatma, Y. (2014). Pengembangan Alat Peraga Matematika untuk Meningkatkan Minat dan Motivasi Belajar Matematika Siswa Sekolah Dasar. Sarwahita, 11(1), 38-43. https://doi.org/10.21009/sarwahita.111.07

Nunnally, J. . (1978). The Study of Change in Evaluation Research: Principal Concerning Measurement, Experimental Design and Analysis. Sage Publication.

Nurfillaili, U., T, M. Y., \& Anggereni, S. (2016). Pengembangan Instrumen Tes Hasil Belajar Kognitif Mata Pelajaran Fisika pada Pokok Bahasan Usaha dan Energi SMA Negeri Khusus Jeneponto Kelas XI Semester I. Jurnal Pendidikan Fisika, 4(2), 83-87. http://repositori.uin-alauddin.ac.id/7539/1/Fitria Nengsih.pdf

Pinilih, Wahyu, F., Budiharti, R., \& Ekawati, E. Y. (2013). Pengembangan Instrumen Penilaian Produk Pada Pembelajaran IPA untuk Siswa SMP. Jurnal Pendidikan Fisika, 1(2). http://www.jurnal.fkip.uns.ac.id/index.php/\%0Apfisika/article/viewFile/2798/1914

Prasetyarini, A., Fatmaryanti, S. D., \& R. Wakhid Akhdinirwanto. (2013). Pada Siswa Smp Negeri I Buluspesantren Kebumen. Radiasi, 2(1), 7-10.

Putranti, N. (2013). Cara Membuat Media Pembelajaran Online Menggunakan Edmodo. Jurnal Pendidikan Informatika Dan Sains, 2(2), 139-147.

Rizta, A., \& Antari, L. (2018). Pengembangan Tes Kemampuan Komunikasi Matematis Pada Materi Sistem Persamaan Linear Untuk Mahasiswa Calon Guru Matematika. AKSIOMA: Jurnal Program Studi Pendidikan Matematika, 7(2), 291-299. https://doi.org/10.24127/ajpm.v7i2.1525

Samsul, P., \& Mutmainnah. (2018). Pengembangan Instrumen Penilaian Autentik pada Pembelajaran dengan Pendekatan Scientific. Edumaspul - Jurnal Pendidikan, 2(1), 1-10. https://doi.org/10.33487/edumaspul.v2i1.20

Saputri, V. A. C., \& Dewi, N. R. (2014). Pengembangan Alat Peraga Sederhana Eye Lens Tema Mata Kelas VIII untuk Menumbuhkan Keterampilan Peserta Didik. Jurnal Pendidikan IPA Indonesia, 3(2), 109115.

Scholtes, V. A., Terwee, C. B., \& Poolman, R. W. (2010). What Makes A Measurement Instrument Valid and Reliable? Injury, 42(3), 1-5. https://doi.org/10.1016/j.injury.2010.11.042

Silalahi, A. (2017). Development Research (Penelitian Pengembangan) dan Research \& Development (Penelitian \& Pengembangan) Dalam Bidang Pendidikan/Pembelajaran. Seminar \& Workshop Penelitian Disertasi Program Doktoral Pasca Sarjana Universitas Negeri Medan, July, 1-13. https://doi.org/10.13140/RG.2.2.13429.88803/1

Sitzia, J. (1999). How Valid and Reliable Are Patient Satisfaction Data? An Analysis of 195 Studies. International Journal for Quality in Health Care, 11(4), 319-328. https://doi.org/10.1093/intqhe/11.4.319

Sudarwanto, \& Hadi, I. (2014). Pengembangan Alat Peraga Pembelajaran Matematika Sekolah Dasar Untuk Meningkatkan Kemampuan Berpikir Matematis Siswa. Sarwahita, 11(1), 32-37. https://doi.org/10.21009/sarwahita.111.06

Suratno, A. (2016). Pengembangan Instrumen Penilaian Kompetensi Praktikum Engine Siswa SMK Program Keahlian Teknik Otomotif Developing Assessment Instruments in Competence Practice Engine Student in SMK Automotive Engineering Program. ANOS Journal Of Mechanical Engineering Education, 11(1), 2528-2700.

Susiatin. (2019). Meningkatkan Kemampuan Guru Dalam Menyusun Kisi-Kisi Soal dengan Metode Pendampingan Pola "OCF" di SDN Yanti Jogoroto. Jurnal Dinamika Manajemen Pendidikan, 4(1), 1724. https://doi.org/10.26740/jdmp.v4n1.p17-24

Triana, D., \& Oktavianto, W. O. (2013). Relevansi Kualifikasi Kontraktor Bidang Teknik Sipil terhadap Kualitas Pekerjaan Proyek Konstruksi di Provinsi Banten. Jurnal Fondasi, 1(1), 182-190.

Wales, G. V., Mandey, S. L., \& Wenas, R. S. (2017). Pengaruh Budaya Organisasi, Gaya Kepemimpinan, Dan Disiplin Kerja Terhadap Kinerja Karyawan Pt. Bank Tabungan Negara (Persero) Tbk. Kantor Cabang Manado. Jurnal EMBA: Jurnal Riset Ekonomi, Manajemen, Bisnis Dan Akuntansi, 5(3), 4435-4444. https://doi.org/10.35794/emba.v5i3.18645

Yazd, T. J. (2009). The Importance of Classroom Assesment and Evaluation in Educational System. Proceedings of the 2nd International Conference of Teaching and Learning, 1-9. http://teachingonpurpose.org/btp/summer2014/thomsen_2014.pdf

Yuliyanti, N. (2016). Pengaruh Model Inkuiri Terbimbing Berbasis Lingkungan terhadap Kemampuan Pemahaman Konsep dan Karakter. Cakrawala Pendas, 2(2), 1-10. 